\title{
Factors Affecting Intention to Transact by Electronic Payment in Supermarkets in Hanoi (Vietnam)
}

\author{
Thi Huong Do \\ School of Trade and International Economics, National Economics University \\ 207 Giai Phong Road, Hai Ba Trung District, Hanoi, Vietnam \\ Email: dthuong@neu.edu.vn \\ Huu Hien Nguyen \\ School of Trade and International Economics, National Economics University \\ 207 Giai Phong Road, Hai Ba Trung District, Hanoi, Vietnam \\ Email: hienhuubn@gmail.com \\ Quynh Duong Nguyen \\ School of Trade and International Economics, National Economics University \\ 207 Giai Phong Road, Hai Ba Trung District, Hanoi, Vietnam \\ Email: duongnq.neu@gmail.com \\ Thu Ha Bui \\ School of Trade and International Economics, National Economics University \\ 207 Giai Phong Road, Hai Ba Trung District, Hanoi, Vietnam \\ Email: buithuha101@gmail.com
}

\begin{abstract}
The study is conducted based on 391 observational samples in Hanoi with the context that Vietnam is promoting digital transformation in all aspects of life. Research has shown that: "Performance Expectancy", "Effort Expectancy", "Social Influence", "Facility Conditions" and "Security and Privacy" have a positive impact on the e-payment intention of shoppers in supermarkets in Hanoi, especially Facility Condition is the most influential factor. In addition, the result also found that the age variable also acts as a crucial driver factor in the process of forming human intentions, while the gender variable has no impact on that process. The study of factors that can affect the intention of electronic payment contributes more theoretical basis in this field, as well as provide a more realistic view of the situation of using electronic payment in Vietnam in general, creating a driving force for the promotion of the development of electronic payment regularly in terms of frequency of application and diversity of application forms. In this study, the authors, besides inheriting domestic and foreign studies on electronic payment, also develop innovative points compared to previous studies. The study uses the new approach to study electronic payment through transactions in supermarkets and assess the role of demographic variables on user intention.
\end{abstract}

Keywords: electronic payment, supermarket, solutions

DOI: $10.7176 / \mathrm{EJBM} / 13-11-02$

Publication date:June $30^{\text {th }} 2021$

\section{Introduction}

Nowadays, the technological disruption is revolutionizing the world by making the financial systeam more effective and innovative. There is no doubt that the digital technology have transformed almost financial industry in Vietnam at unprecedented scale. According to GlobalData, the number of card payment in Vietnam has increased more than 5 times in the past 5 years, increasing from 56 million in 2015 to 271 million in 2019 at a strong CAGR of $48.3 \%$. Vietnam is the fastest-growing market in the world in terms of the number of Vietnamese making mobile payment in stores (according to Pwc). Therefore, Vietnam has many opportunities to bring electronic payment to life and the potential to widely apply this payment method to the supermarket system - the most important retail channel in consumers' lives.

Electronic payment has been around since the 1870s when Western Union launched an electronic money transfer (EFT) service in 1871. In the 1910s, the U.S. Federal Reserve started using the telegraph to transfer money. Electronic payment is defined as "a method or manner of transferring money from a buyer to a seller or from one party to another by electronic means without the use of cash or checks" (Rachna, 2013). In addition, with the approach of Adeoti et al. (2012), an electronic payment system is refered as electronic means of making payment for goods and services purchased online in supermarkets and shopping mall. It is believed that many online payment systems have developed over the years (Koponen, 2006). These systems can be classified into accountbased systems and crypto-based systems. 
Previous reseachers have pointed out some factors affecting the intention of using E-payment. "Performance Expectancy", "Effort Expectancy", and "Social Influence" are agreed to positively impact adopting electronic payment methods in many researches like Junadi et al. (2015); Salloum et al. (2019); Aseng et al., (2020). As a result, these factors are believed to be crucial factors to forming payment intention. However, Trust and Security are believed to be the main influencing factors by another group of researchers (Culnan \& Armstrong, 1999; Miyazaki \& Fernandez, 2000; Changsu Kim et al., 2010). In addition, some authors also mentioned culture, credibility, benefits as factors that may positively affect the intention of using E-payment (Mat Shafie et al., 2020; Panhwer et al., 2020).

Through the evaluation of domestic and international research, three gaps are found to be exploited and completed. Firstly, reasearches in Vietnam mostly focus on a specific electronic payment like credit card or debit card while lacking an overview about e-payment in general. Secondly, a context of studying electronic payment in supermarkets in a big city (Hanoi) seems to gain little attention from researchers in Vietnam, even in the world. Lastly, assessment of the moderating of demographic factors such as age and gender in the correlation between independent variables and the consumer's electronic payment intention rarely mentions in studies.

With the study "Factors affecting the intention to transact by electronic payment in supermarkets in Hanoi", the result has pointed out five factors including: "Performance Expectancy", "Effort Expectancy", "Social Influence", "Facility Condition", "Security and Privacy" have a positive influence on the intention of electronic payment in supermarkets in Hanoi. At the same time, the group also concluded that demographic factors like gender variables does not influence the formation or promotion of this intention in each person in urban areas where economic and education have developed. On the other hand, age variables have a slight impact on this correalion. This research is expected to ameliorate the adoptation of electronic payment in Hanoi.

Our article is structured into five sections. After this introduction, Section 2 reviews existed related documents Next, Section 3 deals with the hypotheses, empirical models, and research methods used in this article. The research results are presented in Section 4. Finally, Section 5 displays conclusions, limits of reasearch, and recommendations for promotion intention of using E-payment in supermarkets in Hanoi.

\section{Literature Review}

Since its inception, there have been a lot of researches surrounding aspects of electronic payment. A group of scientists focuses on studying electronic payment systems (EPS) from the point of view of system builders and recommendations related to improve the quality and performance of the system. However, Ogedebe et al. (2012) study EPS and point out some system problems from the point of view of customers, merchants and provide some security measures for users. The difficulties for EPS and proposes some solutions to improve the quality of the electronic payment framework are pointed out by Tsiakis (2005). EPS is considered as one of the critical technological innovations with benefits such as offering quick and easy transaction processing but also comes with certain risks such as security issues (Bogdan-Alexandru Urs , 2015). It is undeniable that the appearance of EPS is a new turning point in payment method, but the potential dangers from this are always seen as threats. As a reuslt, suggestions are made to overcome these inconveniences.

In addition, most researchers are looking at electronic payment from the perspective of user behaviour and mainly apply TAM (Technology Acceptance Model) and UTAUT (Unified Theory of Acceoptance and Use of Technology) models - popular models to study technology use behaviour. And specifically with the circumstances of the behaviour of using electronic forms of payment. Junadi and Sfenrianto (2015); Mat Shafie et al. (2020); Panhwer et al. (2018) all prove that factors such as: "Performance Expectancy", "Effort Expectancy", "Social Influence" are three factors of the UTAUT model that have the most positive impact towards electronic payment intention.

Besides Trust and Security are taken into consideration to evaluate the intention of electronic payment. Changsu Kim et al. (2010) find that technical protections and security statements are essential factors in increasing the "Security Awareness" among consumers. "Security Awareness" also has a positive impact on "Perceived Trust" which has a strong effect on the choice of electronic payment. This result is also consistent with the conclusions of previous researchers such as Culnan and Armstrong (1999); Miyazaki and Fernandez (2000). On the contrary, there are still some studies that show that the two factors "Security" and "Trust" are not important factors affecting the behavior of electronic payment users (Ming - Yen Toeh et al., 2013; Salloum et al., 2019 - for people with university education or higher; Aseng, 2020 - for Generation Z). However, these two groups of opinions are not completely contradictory but have complementary values to provide us a more comprehensive view of electronic payment. Although there is a study: "Factors promoting and limiting the use of electronic payment by Kenyans: A survey of supermarkets in Thika town" (Kenya is a country in East Africa) which mentions about e-payment in supermarkets. However, the forms that people in Thika use are not numerous, mainly credit cards; sample size is not specific enough, and especially considering only under two groups of variables are benefits and challenges.

The assessment of factors affecting the intention to pay electronically is quite comprehensive. Still, the general limitation of these studies is that the research sample is not diverse in age group, not yet representative to 
assess the trend of using the electronic payment of everyone. These limitations also stem from the failure to determine the demographic factor as a moderator in the research hypotheses. In addition, current studies are studying electronic payment in a general context and are mainly directed at online purchases. In Vietnam, most of the researchers focus on several specific forms of E-payment (Nhat Vuong et al., 2019; Nghi Phan and Dung Dang, 2020; PHUONG, N. N. et al., 2020). While there is not much research on electronic payment in general, epsecially there is no research on e-payment in specific points like supermarkets, shops, convenience stores,...

\section{Hypothesis, Empirical Models, and Research Methods}

3.1. Hypothesis

To examine factors affecting the intentions of using e-payment in supermarkets, the authors concentrate on building some hypotheses below, including five different independent variables: Performance Expectancy, "Effort Expectancy", "Social Influence", "Facility Condition", Security and two moderate variables: Age, Gender. Gerbing and Anderson (1988) define "Intention" as "a state of mind consisting of individual experiences and behaviours for a particular purpose or behaviour". "Intention" refers to an individual's willingness to perform a particular behaviour (Yadav \& Pathak, 2017).

H1: "Performance Expectancy" is positively correlated with the intention to make transactions through electronic payment in supermarkets in Hanoi.

"Performance Expectancy" is defined by Venkatesh et al. (2003) as "the degree to which an individual believes that using a system will help them achieve job performance”. Studies by Arvidsson (2014), Mallat (2007) and Rogers (1976) suggest that "Performance Expectancy" is the degree to which individuals consider electronic payment to have a relative advantage over other methods such as cash. Within the scope of this study, "Performance Expectancy" is defined as the level of effectiveness that individuals believe using electronic payment in transactions in supermarkets will achieve. Venkatesh (2003) demonstrates that "Performance Expectancy" is the most influential factor on intention to use - the results are consistent with previous studies from Agarwal and Prasad (1998); Compeau and Higgins (1995); Davis et al. (1992); Taylor and Todd (1995); Thompson et al. (1991); Venkatesh and Davis (2000).

H2: "Effort Expectancy" is positively correlated with the intention to make transactions through electronic payment in supermarkets in Hanoi.

"Effort Expectancy" is believed to be "the degree of ease associated with use" by Venkatesh et al. (2003). Davis (1989) argues that despite the benefits that technology brings, consumers may not accept the use of services that require a lot of effort in help. He finds that "Effort Expectancy" directly affects the intention to use mobile services. Therefore, if consumers find mobile payment services easy to use, they will be likely to use those services (Nguyen et al., 2016).

H3: Social Influnce is positively correlated with the intention to make transactions through electronic payment in supermarkets in Hanoi.

"Social Influence" is defined as the degree to which an individual perceives that important people believe they should use the new technological system (Venkatesh, 2003). "Social Influence" is a proven factor that substantially impacts intention to use from behavioural models such as TPB (Ajzen, 1991) and UTAUT models (Venkatesh, 2003). Various authors (Tarhini et al., 2016; Mborokoh, 2015; Tan et al., 2014) have demonstrated "Social Influence" as an important driver leading to the formation of intention to use. While Mallat et al. (2008) reveal that social pressure is positively related to intention to use mobile ticketing service, Yang et al. (2012) conclude that influence from friends, colleagues, businesses and others acts as a profound factor influencing the adoption of mobile payment.

H4: "Facility Condition"s is positively correlated with the intention to make transactions through electronic payment in supermarkets in Hanoi.

In their study, Venkatesh et al. (2003) state that "Facility Conditions" is "the degree to which an individual believes that technical and organizational infrastructure exists to support the use of the system". In line with the content of the study, "Facility Conditions" is defined as the degree to which consumers believe that the factors include technical infrastructure such as means of payment, Internet; personal understanding of electronic payment and the assist from supermarkets to apply electronic payment in transactions. According to Huang and Kao (2015), it is said that the baseline conditions have a significant impact on the use and application behaviour of the technology. Naranjo-Zolotov et al. (2019) indicate that an individual has easy access to resources such as computers, smartphones, internet connections, support chat rooms, phone lines, or other favourable conditions will increase their intention to use electronic channels.

H5: "Security and Privacy" is positively correlated with the intention to make transactions through electronic payment in supermarkets in Hanoi.

In the field of online payment, Security can be defined as protecting the details of transactions and customers from internal and external fraud or illegal use (Mat Shafie et al., 2020). Malhotra et al. (2004) propose four aspects of security: "personal data collection", "customer's perception of control over personal data" "customer perception 
of the process" and "information security and how the organization uses personal information". The correlation between security, personal data safety and the intention to use has been demonstrated by Neama et al. (2016) in their topic. Moreover, Ashrafi and Ng (2008) have shown that security and risk perception are significant concerns in electronic payment systems.

H6a: Effect of "Performance Expectancy" on the intention of the younger to transact with electronic payment is more significant than that of the older.

H6b: Effect of "Effort Expectancy" on the intention of the younger to transact with electronic payment is more significant than that of the older.

H6c: Effect of "Social Influence" on the intention of the younger to transact with electronic payment is more significant than that of the older.

In the UTAUT model of Venkatesh (2003), age variable influences the degree of impact of factors on the intention to accept technology. Based on the demographic characteristics of Hanoi consumers and their access to technology, the sample is divided into five age groups: "under 21 years old", "from 21 to 30 years old", "from 31 to 40 years old", "from 41 and 50 years old" and "over 50 years old". From there, the above hypotheses are proposed to test the influence of this variable on the influence of the variables "Performance Expectancy", "Effort Expectancy" and "Social Influence" on "Intention".

H7a: Effect of "Performance Expectancy" on the intention of men to transact using electronic payment is more significant than that of women.

H7b: Effect of "Effort Expectancy" on the intention of women to transact using electronic payment is more significant than that of men.

H7c: Effect of "Social Influence" on the intention of women to transact using electronic payment is more significant than that of men.

A conceptual framework is displayed in Figure 1:

Figure 1: Conceptual framework

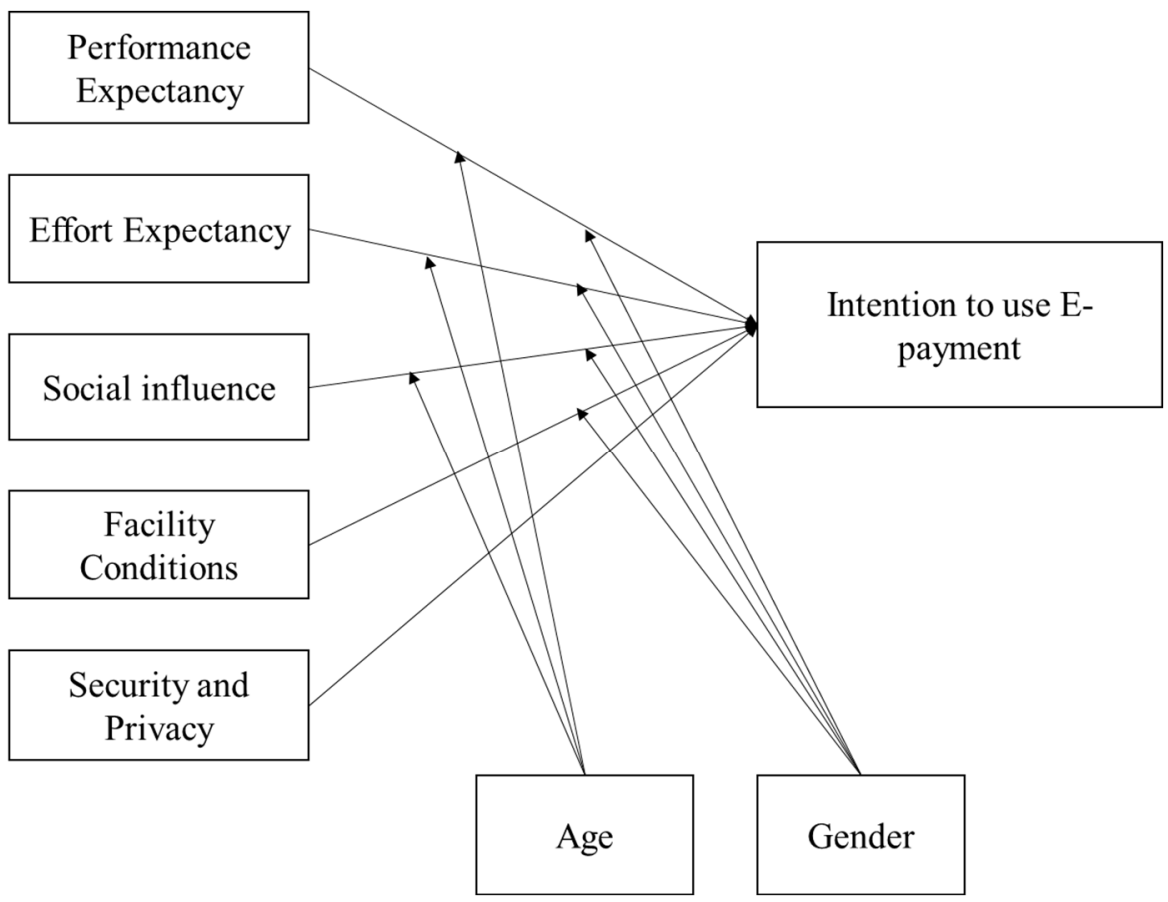

\subsection{Empirical Model}

To consider and justify the effects of 5 different independent variables on personal development, the quantitative research method is usually applied in previous researches to investigate the correlation and regression model with assistance from the software. Therefore, in this research, the authors will follow the quantitative research method into regression models with the independent variable: "Performance Expectancy", "Effort Expectancy", "Social Influence", "Facility Conditions" and "Security and Privacy" with the assistance of IBM - SPSS 22 version 22.0. Model: $\mathrm{PI}=\alpha+\beta_{1} * \mathrm{PE}+\beta_{2} * \mathrm{EE}+\beta_{3} * \mathrm{SI}+\beta_{4} * \mathrm{FC}+\beta_{5} * \mathrm{SP}+\varepsilon$

Where: $\alpha, \beta_{1}, \beta_{2}, \beta_{3}, \beta_{4}$, and $\beta_{5}$ are coefficients

$$
\varepsilon \text { is error }
$$


Table 1: Lists of dependent and independent variables of the regression models

\begin{tabular}{|c|c|c|c|c|}
\hline Variable & Meaning & Determined by & Role & Model \\
\hline \multirow{3}{*}{ PI } & \multirow{3}{*}{$\begin{array}{l}\text { Payment } \\
\text { Intention }\end{array}$} & $\begin{array}{l}\text { I will use electronic payment instead of cash when } \\
\text { shopping at the supermarket. }\end{array}$ & $\begin{array}{l}\text { Dependent } \\
\text { variable }\end{array}$ & PI1 \\
\hline & & I will often pay electronically at the supermarket. & $\begin{array}{l}\text { Dependent } \\
\text { variable }\end{array}$ & PI2 \\
\hline & & $\begin{array}{l}\text { I will recommend to friends, colleagues and relatives to } \\
\text { use electronic payment when going to the supermarket. }\end{array}$ & $\begin{array}{l}\text { Dependent } \\
\text { variable }\end{array}$ & PI3 \\
\hline \multirow{5}{*}{$\mathrm{PE}$} & \multirow{5}{*}{$\begin{array}{l}\text { "Performance } \\
\text { Expectancy" }\end{array}$} & I think electronic payment is useful in my daily life. & $\begin{array}{l}\text { Independent } \\
\text { variable }\end{array}$ & PE1 \\
\hline & & $\begin{array}{l}\text { Using electronic payment can increase my chances of } \\
\text { achieving things that are important to me. }\end{array}$ & $\begin{array}{l}\text { Independent } \\
\text { variable }\end{array}$ & PE2 \\
\hline & & $\begin{array}{l}\text { Using electronic payment can help me complete } \\
\text { transactions faster. }\end{array}$ & $\begin{array}{c}\text { Independent } \\
\text { variable }\end{array}$ & PE3 \\
\hline & & Using electronic payment can increase my productivity. & $\begin{array}{l}\text { Independent } \\
\text { variable }\end{array}$ & PE4 \\
\hline & & $\begin{array}{l}\text { Using electronic payment helps me to eliminate } \\
\text { unnecessary difficulties when using cash such as no } \\
\text { money to return, etc. }\end{array}$ & $\begin{array}{l}\text { Independent } \\
\text { variable }\end{array}$ & PE5 \\
\hline \multirow{5}{*}{$\mathrm{EE}$} & \multirow{5}{*}{$\begin{array}{c}\text { "Effort } \\
\text { Expectancy" }\end{array}$} & $\begin{array}{l}\text { The operation with electronic payment is easy to } \\
\text { understand and easy to complete. }\end{array}$ & $\begin{array}{l}\text { Independent } \\
\text { variable }\end{array}$ & EE1 \\
\hline & & The proficient use of electronic payment forms is easy. & $\begin{array}{l}\text { Independent } \\
\text { variable }\end{array}$ & EE2 \\
\hline & & $\begin{array}{l}\text { Using electronic payment does not take much time to } \\
\text { learn. }\end{array}$ & $\begin{array}{l}\text { Independent } \\
\text { variable }\end{array}$ & EE3 \\
\hline & & $\begin{array}{l}\text { The instructions for using electronic payment in } \\
\text { supermarkets are clear, understandable, and can be easily } \\
\text { followed. }\end{array}$ & $\begin{array}{l}\text { Independent } \\
\text { variable }\end{array}$ & EE4 \\
\hline & & $\begin{array}{l}\text { Using electronic payment in transactions in supermarkets } \\
\text { is easy and convenient. }\end{array}$ & $\begin{array}{l}\text { Independent } \\
\text { variable }\end{array}$ & EE5 \\
\hline \multirow{5}{*}{ SI } & \multirow{5}{*}{$\begin{array}{l}\text { "Social } \\
\text { Influence" }\end{array}$} & Almost everyone around me uses electronic payment. & $\begin{array}{l}\text { Independent } \\
\text { variable }\end{array}$ & SI1 \\
\hline & & $\begin{array}{l}\text { People who are important to me all think that I should pay } \\
\text { electronically. }\end{array}$ & $\begin{array}{l}\text { Independent } \\
\text { variable }\end{array}$ & SI2 \\
\hline & & $\begin{array}{l}\text { The supermarkets I go to all encourage electronic } \\
\text { payment. }\end{array}$ & $\begin{array}{l}\text { Independent } \\
\text { variable }\end{array}$ & SI3 \\
\hline & & $\begin{array}{l}\text { Influential celebrities advocate digital transformation in } \\
\text { payment. }\end{array}$ & $\begin{array}{l}\text { Independent } \\
\text { variable }\end{array}$ & SI4 \\
\hline & & I get a discount code when I use e-payment. & $\begin{array}{l}\text { Independent } \\
\text { variable }\end{array}$ & SI5 \\
\hline \multirow{5}{*}{$\mathrm{FC}$} & \multirow{5}{*}{$\begin{array}{l}\text { "Facility } \\
\text { Conditions", }\end{array}$} & $\begin{array}{l}\text { I have the necessary resources (smartphone, bank } \\
\text { account, e-wallet) to use electronic payment }\end{array}$ & $\begin{array}{l}\text { Independent } \\
\text { variable }\end{array}$ & FC1 \\
\hline & & $\begin{array}{l}\text { I have the necessary knowledge to make electronic } \\
\text { payment (knowledge of using smartphones, the internet } \\
\text { and other technologies). }\end{array}$ & $\begin{array}{l}\text { Independent } \\
\text { variable }\end{array}$ & FC2 \\
\hline & & $\begin{array}{l}\text { Electronic payment is compatible with other } \\
\text { technologies. }\end{array}$ & $\begin{array}{l}\text { Independent } \\
\text { variable }\end{array}$ & FC3 \\
\hline & & $\begin{array}{l}\text { There are staff to guide and support me to make electronic } \\
\text { payment. }\end{array}$ & $\begin{array}{l}\text { Independent } \\
\text { variable }\end{array}$ & FC4 \\
\hline & & $\begin{array}{l}\text { There is a device available at the supermarket for me to } \\
\text { make electronic payment. }\end{array}$ & $\begin{array}{l}\text { Independent } \\
\text { variable }\end{array}$ & FC5 \\
\hline
\end{tabular}




\begin{tabular}{|c|c|c|c|c|}
\hline Variable & Meaning & Determined by & Role & Model \\
\hline \multirow{5}{*}{ SP } & \multirow{5}{*}{$\begin{array}{l}\text { "Security and } \\
\text { Privacy" }\end{array}$} & $\begin{array}{l}\text { I am not worried about the security of financial } \\
\text { transactions via electronic payment. }\end{array}$ & $\begin{array}{c}\text { Independent } \\
\text { variable }\end{array}$ & SP1 \\
\hline & & $\begin{array}{l}\text { I am sure that the information submitted via electronic } \\
\text { payment is not intercepted or modified by authorized third } \\
\text { parties. }\end{array}$ & $\begin{array}{l}\text { Independent } \\
\text { variable }\end{array}$ & $\mathrm{SP} 2$ \\
\hline & & $\begin{array}{l}\text { I think the parties involved in electronic payment (banks, } \\
\text { e-wallets, etc.) have a high commitment to ensure users' } \\
\text { privacy. }\end{array}$ & $\begin{array}{l}\text { Independent } \\
\text { variable }\end{array}$ & SP3 \\
\hline & & $\begin{array}{l}\text { I think that the parties involved in electronic payment } \\
\text { only collect personal data of users that is necessary for its } \\
\text { operation. }\end{array}$ & $\begin{array}{l}\text { Independent } \\
\text { variable }\end{array}$ & SP4 \\
\hline & & $\begin{array}{l}\text { I think that the parties involved in electronic payment do } \\
\text { not provide my personal information to other companies } \\
\text { without my consent. }\end{array}$ & $\begin{array}{l}\text { Independent } \\
\text { variable }\end{array}$ & SP5 \\
\hline
\end{tabular}

\subsection{Research Methods}

Sample collection and processing process:

3.3.1 Implementing a Selection of the Research Objects and Scopes

The number of survey samples is suitable for factor analysis which is at least five times higher than the total number of observed variables (Comrey, 1973; Roger, 2006). In this study, the number of observed variables is 28 , so the minimum suitable scale for factor analysis is $5 * 28=140$ survey samples. According to the plan, the total number of questionnaires distributed is 500 , based on the team's ability and time to collect. The survey form is distributed online or in-person based on the most appropriate accessibility for the survey subjects. In which, there are 100 face-to-face surveys and 400 online surveys.

3.3.2. Collecting Research Data

To collect research data, we conducted a designed questionnaire with a large set of extensive questionnaires, including:

Part 1: Questions about personal information related to demographic factors such as: Where to live and work, Gender, Age.

Part 2: Questions to assess the impact of the proposed factors on the intention to transact by e-payment with the form of level selection according to the Likert 5 scale, from "totally disagree" to "strongly agree".

The team handed in the questionnaires online or offline according to the accessibility of the subjects.

3.3.3. Data Processing

The data after being collected through the questionnaires was entered into Microsoft Excel. Next, we recalculated the students' responses based on a Likert scale with a graded score of 1-5 corresponding to the levels of agreement from full disagree, disagree, normal, agree, and totally agree. At the same time, we eliminated all incomplete answer forms and inconsistent answers. As samples are winnowed, 391 samples are qualified.

Data that is collected and processed are analyzed by the methods as Descriptive statistics analysis to describe basic quantitative characteristics of data; Correlation and regression analysis to measure linear correlations between variables in regression models through the following steps:

(1) Sort out statistical characteristics of the observed sample

(2) Test the quality of the measurement by Cronbach's Alpha

(3) Use Exploratory Factor Analysis (EFA) to separate all the variables into the exclusive element to support the following steps

(4) Parse and analyze the empirical models by using SPSS 22

(5) Test the results from the empirical models.

\section{Results}

4.1. Descriptive Analysis

According to statistics, 357 people have experience using electric payment in supermarkets out of 391 survey criteria, accounting for $91.13 \%$. The number signifies that electric payment os being popularized in supermarkets in Hanoi, especially for the youth, who account for a large proportion of survey participants. Among men surveyed, the percentage of people who have never used electric payment is $9.6 \%$. The corresponding figure for women is $8.2 \%$. These two data do not have a big difference compared to each other, which show that the level of experience between the two sexes is similar.

In most age groups, the number of people who have used e-payment in supermarkets has always dominated 
the part that has never used e-payment. The age group of people who are from 31 to 40 years old has the highest rate $(91.2 \%)$ of experiencing this method and the age group of people who are over 50 has the lowest rate with $88.55 \%$. However, the ratio difference here is not too much, so the difference is not too significant.

\subsection{Correlation analysis}

Table 2: Pearson correlation

** Correlation is significant at the 0.01 level

\begin{tabular}{|c|c|c|c|c|c|}
\hline Factor & $\begin{array}{c}\text { "Performance } \\
\text { Expectancy" }\end{array}$ & $\begin{array}{c}\text { "Effort } \\
\text { Expectancy" }\end{array}$ & $\begin{array}{c}\text { "Social } \\
\text { Influence" }\end{array}$ & $\begin{array}{c}\text { "Facility } \\
\text { Conditions" }\end{array}$ & Security \\
\hline $\begin{array}{c}\text { "Performance } \\
\text { Expectancy" }\end{array}$ & 1 & $0,541^{* *}$ & $0,305^{* *}$ & $0,457^{* *}$ & $0,291^{* *}$ \\
\hline "Effort Expectancy" & $0,541^{* *}$ & 1 & $0,306^{* *}$ & $0,524^{* *}$ & $0,415^{* *}$ \\
\hline "Social Influence" & $0,305^{* *}$ & $0,306^{* *}$ & 1 & $0,470^{* *}$ & $0,563^{* *}$ \\
\hline "Facility Conditions" & $0,457^{* *}$ & $0,524^{* *}$ & $0,470^{* *}$ & 1 & $0,396^{* *}$ \\
\hline "Security and Privacy" & $0,291^{* *}$ & $0,415^{* *}$ & $0,563^{* *}$ & $0,396^{* *}$ & 1 \\
\hline "Intention to use" & $0,456^{* *}$ & $0,512^{* *}$ & $0,585^{* *}$ & $0,630^{* *}$ & $0,495^{* *}$ \\
\hline
\end{tabular}

Sig coefficient. correlation of independent variables PE, EE, SI, FC, SP with dependent variable PI are all less than 0.05 , respectively. So, there is a linear relationship between these independent variables and the PI variable.

\subsection{Regression Model}

4.3.1. Measuring Reliability by a Factor Cronbach's Alpha

For P'E variables, the test results show that the observed P.E variables have an appropriate total correlation coefficient $(\geq 0.3$ ). Cronbach's Alpha coefficient $=0.905 \geq 0.8$ so the variables PE1, PE2, PE3, PE4 and PE4 meet the requirements of reliability and are an excellent measuring scale representing the variable P.E.

For E.E variables, the test results illustrate that the observed variables E.E have an appropriate correlation coefficient of total variables $(\geq 0.3)$. Cronbach's Alpha coefficient $=0.902 \geq 0.8$, so variables EE1, EE2, EE3, $\mathrm{EE} 4$, and EE5 meet reliability requirements and are a magnificent measurement scale representing the variable E.E.

For S.I variables, the test results indicate that the S.I observed variables have an appropriate total correlation coefficient $(\geq 0.3)$. Cronbach "s Alpha coefficient $=0.832 \geq 0.8$, so the variables SI1, SI2, SI3, SI4, and SI5 meet the reliability requirements and are a perfect measurement scale representing the S.I variable.

For F.C variables, the test results indicate that the F.C observed variables have an appropriate total correlation coefficient $(\geq 0.3)$. Cronbach "s Alpha coefficient $=0.842 \geq 0.8$, so the variables FC1, FC2, FC3, FC4, and FC5 meet the reliability requirements and are a very acceptable measurement scale representing the F.C variable.

And for S.P variables, the test results show that the S.P observed variables all have appropriate correlation coefficients $(\geq 0.3)$. Cronbach "s Alpha coefficient $=0.897 \geq 0.5$ so the variables SP1, SP2, SP3, SP4, and SP5 are solid scales for S.P.

The test results show that the observed P.I variables have an appropriate total correlation coefficient $(\geq 0.3)$ for P.I variables. Cronbach's Alpha coefficient $=0.864 \geq 0.8$ so the variables PI1, PI2, and PI3 meet the reliability requirements and are a reliabe measuring scale representing the variable PI. 


\subsubsection{Analysis of discovery factors EFA}

Table 3: Total Variance Explained

\begin{tabular}{|c|c|c|c|c|c|}
\hline \multirow[t]{2}{*}{ Variables } & \multicolumn{5}{|c|}{ Factor Group } \\
\hline & 1 & 2 & 3 & 4 & 5 \\
\hline PE2 & 0,854 & & & & \\
\hline PE3 & 0,828 & & & & \\
\hline PE1 & 0,817 & & & & \\
\hline PE5 & 0,788 & & & & \\
\hline PE4 & 0,723 & & & & \\
\hline SP2 & & 0,825 & & & \\
\hline SP5 & & 0,822 & & & \\
\hline SP4 & & 0,815 & & & \\
\hline SP3 & & 0,797 & & & \\
\hline SP1 & & 0,659 & & & \\
\hline EE3 & & & 0,809 & & \\
\hline EE4 & & & 0,791 & & \\
\hline EE2 & & & 0,767 & & \\
\hline EE5 & & & 0,756 & & \\
\hline EE1 & & & 0,750 & & \\
\hline SI2 & & & & 0,768 & \\
\hline SI3 & & & & 0,761 & \\
\hline SI1 & & & & 0,756 & \\
\hline SI4 & & & & 0,691 & \\
\hline \multicolumn{6}{|l|}{ SI5 } \\
\hline $\mathrm{FC} 2$ & & & & & 0,789 \\
\hline FC3 & & & & & 0,787 \\
\hline $\mathrm{FC1}$ & & & & & 0,783 \\
\hline FC5 & & & & & 0,628 \\
\hline FC4 & & & & & 0,509 \\
\hline Eigenvalues & 9,383 & 3,345 & 1,837 & 1,755 & 1,244 \\
\hline \multicolumn{5}{|c|}{ Total value of variance extracted } & $70,259 \%$ \\
\hline \multicolumn{5}{|c|}{ KMO $=0,913$} & Sig $=0,000$ \\
\hline
\end{tabular}

Factor loading of SI5 does not appear in any group, so the research team will remove factor SI5 and conduct EFA analysis for the remaining elements.

Table 4: Remaining variables after winnowing in the models

\begin{tabular}{|c|c|c|c|c|c|}
\hline \multirow[t]{2}{*}{ Variables } & \multicolumn{5}{|c|}{ Factor Group } \\
\hline & 1 & 2 & 3 & 4 & 5 \\
\hline PE2 & 0,854 & & & & \\
\hline PE3 & 0,829 & & & & \\
\hline PE1 & 0,818 & & & & \\
\hline PE5 & 0,788 & & & & \\
\hline PE4 & 0,726 & & & & \\
\hline SP2 & & 0,828 & & & \\
\hline SP5 & & 0,827 & & & \\
\hline SP4 & & 0,820 & & & \\
\hline SP3 & & 0,800 & & & \\
\hline SP1 & & 0,661 & & & \\
\hline EE3 & & & 0,809 & & \\
\hline EE4 & & & 0,790 & & \\
\hline EE2 & & & 0,766 & & \\
\hline EE5 & & & 0,756 & & \\
\hline EE1 & & & 0,753 & & \\
\hline $\mathrm{FC} 2$ & & & & 0,797 & \\
\hline FC3 & & & & 0,794 & \\
\hline
\end{tabular}




\begin{tabular}{|l|l|l|l|l|l|}
\hline \multirow{2}{*}{ Variables } & \multicolumn{5}{|c|}{ Factor Group } \\
\cline { 2 - 6 } & $\mathbf{1}$ & $\mathbf{2}$ & $\mathbf{3}$ & $\mathbf{4}$ & $\mathbf{5}$ \\
\hline FC1 & & & & 0,781 & \\
\hline FC5 & & & & 0,641 & \\
\hline FC4 & & & 0,527 & \\
\hline SI2 & & & & & 0,768 \\
\hline SI1 & & & & 0,756 \\
\hline SI3 & & & & & 0,754 \\
\hline SI4 & & & & 1,752 & 0,677 \\
\hline Eigenvalues & 9,137 & 3,302 & 1,794 & 1,244 \\
\hline Total value of variance extracted & & & \\
\hline
\end{tabular}

The analysis of the EFA discovering factors show that: Because $0.5<\mathrm{KMO}$ coefficient $=0.911<1.000$, the analysis of the factors is consistent with the research data set. In addition, Bartlett's Test of Sphericity has shown that the observed variables in the same factor are correlated with each other due to Sig (Bartlett "s Test) $=0<0.05$.

Factor loading coefficients are all greater than 0.5 and the total value of variance extracted from 5 groups of factors is $71.789 \%$ or the explanatory factors are $71.789 \%$ of the measured variable which is greater than $50 \%$ (satisfying the demanded requirements) and the value of Eigenvalues of these 5 groups of factors are satisfied greater than one. Therefore, it can be said that the original observed variables have converged in 5 groups of factors.

In the original factor groups, no factor groups were combined. Therefore, the initial five groups of factors continue to be used to carry out the subsequent analysis steps.

4.3.3. Regression Models

Table 5: Model Summary

SI Model

\begin{tabular}{|c|c|c|c|c|}
\hline Model & R & R Square & Adjusted R Square & $\begin{array}{c}\text { Std. Error of the } \\
\text { Estimate }\end{array}$ \\
\hline 1 & $0,745^{\mathrm{a}}$ & 0,555 & 0,549 & 4,2310 \\
\hline
\end{tabular}

In the above study, the adjusted R-squared coefficient is 0.549 , which means that the factors in the study contribute $54.9 \%$ (greater than $50 \%$ ) of the change of the dependent variable "Intention to use e-payment". The impact of this change is relatively stable and acceptable in the current e-payment context.

Table 6: ANOVA

\begin{tabular}{|c|c|c|c|c|c|c|}
\hline \multicolumn{2}{|c|}{ Model } & $\begin{array}{c}\text { Sum of } \\
\text { squares }\end{array}$ & df & Mean Square & F & Sig. \\
\hline \multirow{3}{*}{1} & Regression & 144,007 & 5 & 28,801 & 95,856 & 0,000 \\
\cline { 2 - 7 } & Residual & 115,679 & 385 & 0,300 & & \\
\cline { 2 - 7 } & Total & 259,686 & 390 & & & \\
\hline
\end{tabular}

Sig. level in the ANOVA table is used to assess the fit of the model. In this study, the sig value. of the F-test is $0.000(<0.05)$. Therefore, the linear regression model is relatively suitable compared to the population and can be used.

Table 7: Coefficients

\begin{tabular}{|l|c|c|c|c|}
\hline \multirow{2}{*}{ Model } & \multicolumn{2}{|c|}{$\begin{array}{c}\text { Unstandardized } \\
\text { Coefficients }\end{array}$} & \multirow{2}{*}{ Sig. } \\
\cline { 2 - 3 } & B & Std. Error & & \\
\hline (Constant) & $-0,168$ & 0,230 & $-0,730$ & 0,466 \\
\hline PE & 0,129 & 0,051 & 2,529 & 0,012 \\
\hline EE & 0,182 & 0,054 & 3,352 & 0,001 \\
\hline SI & 0,251 & 0,037 & 6,738 & 0,000 \\
\hline FC & 0,407 & 0,056 & 7,293 & 0,000 \\
\hline SP & 0,097 & 0,039 & 2,518 & 0,012 \\
\hline
\end{tabular}

Regression equation:

$$
\mathrm{PI}=-\mathbf{0 , 6 1 8}+\mathbf{0 , 1 2 9} * \mathrm{PE}+\mathbf{0 , 1 8 2} \mathrm{EE}+\mathbf{0 , 2 5 1} * \mathrm{SI}+\mathbf{0 , 4 0 7} * \mathrm{FC}+\mathbf{0 , 0 9 7} * \mathrm{SP}
$$

Sig. coefficient of the t-test, the regression coefficients of the independent variables are all $<0.05$. Therefore, these independent variables are all significant in explaining the dependent variable, none of which is excluded from the model. The VIF coefficients of the independent variables are all $<2$, so there is no multicollinearity. The regression coefficients are all $>0$. Therefore, all the independent variables included in the regression analysis have the same effect as the dependent variable. 


\section{Conclusion and Recommendation}

\subsection{Conclusion}

In general, the majority of survey respondents have used electronic payment in supermarkets (accounting for $91.3 \%$ ), the form of use is also relatively diverse. However, the percentage of people using credit and debit cards is high, followed by e-wallets and mobile payment. Thus, it can be seen that card payment - the traditional form of electronic payment is still dominant, other forms have initially been applied more widely but are still rare. In addition to the preliminary assessments, the results of the regression analysis show that all five factors included in the analysis are positively related to the intention to pay electronically. "Facility Conditions" is the factor that has the strongest impact on the intention of using E-payment, followed by "Social Influence", "Effort Expectancy", "Performance Expectancy". "Security and Privacy" has always been considered as an extremely important factor affecting the decision to apply technology, including electronic payment, according to the conclusion of Oney et al (2017), Kim, C., Tao (2010). However, in this study, "Security and Privacy" is the factor with the least impact.

The research results also show that the moderator variable including "Gender" has no impact on the relationship between key variables and electronic payment intention, as in the conclusion of previous studies by Dabholkar et al. (2002), Meuter et al. (2003), Reinders et al. (2008) on technology adoption. Besides, the results are consistent with the results of Acheampong et al. (2018) as the "Age" factor is believed to have a particular influence and there is a difference in the level of impact between age groups. Specifically, for young people, the factors of "Performance Expectancy", "Effort Expectancy", and "Social Influence" will strongly influence their intention to pay electronically; in contrast to the elderly, the level of impact will be lower.

\subsection{Limitations}

Besides the goals and results achieved, the research team also encountered difficulties and limitations, including:

Firstly, the research topic is still only stopping the study of people's electronic payment from the perspective of behavioural intentions, not progressing to behavioural research.

Secondly, the research is aimed at the area of Hanoi - one of the major cities in Vietnam, so the assessment of the trend of e-payment is still not comprehensive with regions and localities. Because the geographical area also dramatically affects the availability of technology and the level of technology acceptance of the people.

Lastly, the research team examine demographic factors such as Age and Gender, but the sample size is not ideal when young people still make up a large proportion and female accounts for a large proportion (62.7\%).

\subsection{Recommendations}

\subsubsection{For the government}

The research results show that "Facility Condition" is the factor that has the most positive impact on the intention to pay electronically in supermarkets. Therefore, the development of complete and uniform "Facility Condition" is a top priority for promoting the development of electronic payment. From there, the research team proposes the following recommendations:

Firstly, continue to improve mechanisms, policies and legal frameworks for banking activities to adapt to the 4.0 revolution; speed up the improvement and development of the Law on Electronic Transactions.

Secondly, build a legal corridor on security, data protection and privacy protection for consumers.

Finally, strengthen inspection and supervision of activities of commercial banks and Fintech companies.

5.3.2. For payment intermediaries (Commercial banks, Fintech companies)

From the perspective of a payment intermediary channel, building asynchronous and efficient system and developing digital products and services will be the key to making electronic payment widely available to Vietnamese consumers. Thereby, the research team proposes the following recommendations: strengthen communication and financial education for consumers; promote cooperation between payment intermediary service providers; firmly apply technology into its products, focus on investing in digital products and services, improve outcomes, and take customers as the goal.

5.3.3. For supermarket

The supermarket system can actively apply the following suggestions to increase the number of transactions by electronic transaction method - an efficient and easy-to-manage transaction:

Firstly, strengthen infrastructure and support systems to help consumers use electronic payment: build the necessary primary conditions so that consumers can easily apply electronic forms of payment such as Internet connection, POS machine, Q.R. code, etc.; appoint staff to support consumers to use electronic payment in the first payment which is a crucial factor affecting consumers' intention to pay electronically, so supermarkets need to develop this support system.

Secondly, build promotions for customers when transacting electronically; promote advertising about this form of payment in the mass media.

Finally, cooperate with payment intermediaries to offer electronic payment solutions suitable to transaction characteristics in supermarkets. 


\section{References}

Phan Hữu Nghị, \& Đặng Thanh Dung. (2019). Researching on customers' decision to use mobile payment services in Hanoi, Banking magazine.

Acheampong, P., Zhiwen, L., Hiran, K., Serwaa, O., Boateng, F., \&amp; Bediako, I. (n.d.). Examining the Intervening role of age and gender on mobile payment acceptance in Ghana: UTAUT MODEL (2018). Retrieved April 5, 2021, from http://onlinejournal.org.uk/index.php/cajast/article/view/303

Adeoti, O., Osotimehin, K., \& Olajide, O. (2012). Consumer payment pattern and motivational factors for using debit card in Nigeria. International Business Management, 6(3), 352-355.

Agarwal, R., \& Prasad, J. (1998). A conceptual and operational definition of personal innovativeness in the domain of information technology. Information Systems Research, 9(2), 204-215. doi:10.1287/isre.9.2.204

Ajzen, I. (1985). From intentions to actions: a theory of planned behavior. In: Kuhl, J., Beckman, J. (eds) Action Control: From cognitions to behavior Heidelberg, Berlin: Springer, pp. 11-39

Ajzen, I. (1991). The theory of planned behavior. Organizational Behavior and Human Decision Processes, 50(2), 179-211.

Al-Laham, M., Al-Tarawneh, H., \& Abdallat, N. (2009). Development of electronic money and its impact on the central bank role and monetary policy. Proceedings of the 2009 InSITE Conference. doi:10.28945/3328

Arvidsson, N. (2014). Consumer attitudes on mobile payment services - results from a proof of concept test. International Journal of Bank Marketing, 32(2), 150-170.

Aseng, A. C. (2020). Factors influencing generation z intention in using fintech payment services. CogITo Smart Journal, 6(2), 155.

Ashrafi, M. Z., \& Ng, S. K. (2008). Enabling privacy-preserving e-payment processing. Database Systems for Advanced Applications, 596-603.

Barkhordari, M., Nourollah, Z., Mashayekhi, H., Mashayekhi, Y., \& Ahangar, M. S. (2016). Factors influencing adoption of e-payment systems: An empirical study on Iranian customers. Information Systems and EBusiness Management, 15(1), 89-116.

Bogdan-Alexandru Urs, 2015. "Security Issues And Solutions In E-Payment Systems," Fiat Iustitia, Faculty of Law,"Dimitrie Cantemir" Christian University Bucharest, vol. 9(1), pages 172-179, June.

Changsu Kim, Wang Tao, Namchul Shin, Ki-Soo Kim, An empirical study of customers' perceptions of security and trust in e-payment systems, Electronic Commerce Research and Applications, Volume 9, Issue 1, 2010, Pages 84-95, ISSN 1567-4223,

Compeau, D. R., \& Higgins, C. A. (1995). Computer self-efficacy: Development of a measure and initial test. MIS Quarterly, 19(2), 189. doi:10.2307/249688

Comrey, A. L. (1973). A first course in factor analysis. New York, NY: Academic Press.

Culnan, M. J., \& Armstrong, P. K. (1999). Information privacy concerns, procedural fairness, and impersonal trust: An empirical investigation. Organization Science, 10(1), 104-115.

Dabholkar, P. A., and Bagozzi, R. P. 2002. "An attitudinal model of technology-based self-service: moderating effects of consumer traits and situational factors," Journal of the academy of marketing science (30:3), pp 184-201.

Davis, F. D. (1989). Perceived Performance Expectancy, perceived Effort Expectancy, and user acceptance of information technology. MIS Quarterly, 13(3), 319.

Davis, F. D., Bagozzi, R. P., \& Warshaw, P. R. (1992). Extrinsic and intrinsic motivation to use computers in the workplace. Journal of Applied Social Psychology, 22(14), 1111-1132. doi:10.1111/j.15591816.1992.tb00945.x

Huang, C., \& Kao, Y. (2015). UTAUT2 based predictions of factors influencing the technology acceptance of PHABLETS By dnp. Mathematical Problems in Engineering, 2015, 1-23.

Kim, C., Tao, W., Shin, N., \& Kim, K. (2010). An empirical study of customers' perceptions of security and trust in e-payment systems. Electronic Commerce Research and Applications, 9(1), 84-5.

Koponen, A. (2006). E-Commerce, Electronic Payments. Helsinki University of Technology, Telecommunications Software and Multimedia Laboratory.

Junadi, Junadi \& Sfenrianto, Sfenrianto. (2015). A Model of Factors Influencing Consumer's Intention To Use Epayment System in Indonesia. Procedia Computer Science. 59. 214-220.

Malhotra, N. K., Kim, S. S., \& Agarwal, J. (2004). Internet users' information privacy Concerns (iuipc): The construct, the scale, and a causal model. Information Systems Research, 15(4), 336-355.

Mallat, N. (2007). Exploring consumer adoption of mobile payments - a qualitative study. The Journal of Strategic Information Systems, 16(4), 413-432.

Mat Shafie, I. S., Mohd Yusof, Y. L., Mahmood, A. N., Mohd Ishar, N. I., Jamal, H. Z., \& Abu Kasim, N. H. (2020). Factors influencing the adoption of E-Payment: An empirical study in Malaysia. ADVANCES IN BUSINESS RESEARCH INTERNATIONAL JOURNAL, 4(2), 53.

Mbrokoh, A. S. (2015). Exploring the factors That Influence Internet Banking Adoption in Ghana. Journal of 
Internet Banking and Commerce.

Meuter, M. L., Ostrom, A. L., Bitner, M. J., and Roundtree, R. 2003. "The influence of technology anxiety on consumer use and experiences with self-service technologies," Journal of Business Research (56:11), pp 899906.

Ming - Yen Teoh, W., Choy Chong, S., Lin, B., \& Wei Chua, J. (2013). Factors affecting consumers' perception of electronic payment: An empirical analysis. Internet Research, 23(4), 465-485.

Miyazaki, A. D., \& Fernandez, A. (2000). Internet privacy and security: An examination of online retailer disclosures. Journal of Public Policy \&amp; Marketing, 19(1), 54-61.

Naranjo-Zolotov, M., Oliveira, T., \& Casteleyn, S. (2019). Citizens' intention to use and recommend Eparticipation. Information Technology \& People, 32(2), 364-386.

Neama, G., Alaskar, R., \& Alkandari, M. (2016). Privacy, security, risk, and trust concerns in e-commerce. Proceedings of the 17th International Conference on Distributed Computing and Networking.

Nguyen, T. N., Cao, T. K., Dang, P. L., \& Nguyen, H. A. (2016). Predicting consumer intention to use mobile payment SERVICES: Empirical evidence from Vietnam. International Journal of Marketing Studies, 8(1), 117.

Nhat Vuong, B., Thi Hieu, V., \&; Thi Thuy Trang, N. (2019). An empirical analysis of mobile Banking adoption in Vietnam. Gestão E Sociedade, 14(37), 3365-3393. doi:10.21171/ges.v14i37.3078

Ogedebe, P.M., \& Jacob, B.P. (2012). E-payment: Prospects and Challenges in Nigerian Public Sector. International Journal of Modern Engineering Research, vol. 2, no. 5, pp. 3104-3106.

Oney, E., Oksuzoglu Guven, G., \& Hussain Rizvi, W. (2017). The determinants of electronic payment systems usage from consumers' perspective. Economic Research-Ekonomska Istraživanja, 30(1), 394-415. https://doi.org/10.1080/1331677x.2017.1305791

Panhwer, P., Pitafi, A., Memon, M. S., \& Memon, A. (2020). Awareness and reason towards slow adoption of epayment system: Study of hyderabad. Annals of Contemporary Developments in Management \&amp; HR, 2(1), 6-21. doi:10.33166/acdmhr.2020.01.002

PHUONG, N. N., LUAN, L. T., DONG, V. V., \&amp; KHANH, N. L. (2020). Examining Customers' Continuance intentions Towards E-wallet usage: The emergence of mobile payment acceptance in Vietnam. The Journal of Asian Finance, Economics and Business, 7(9), 505-516. doi:10.13106/jafeb.2020.vol7.no9.505

Rachna, P. S. (2013). Issues and Challenges of Electronic Payment Systems. International Journal for Research in, vol. Vol. 2, no. Issue 9/

Reinders, M. J., Dabholkar, P. A., and Frambach, R. T. 2008. "Consequences of forcing consumers to use technology-based self-service," Journal of Service Research (11:2), pp 107-123.

Roger, B. (2006). Estimation and Sample Size Determination for Finite Populations. 10th Edition, CD Rom Topics, Section 8.7, West Chester University of Pennsylvania.

Rogers, E. M. (1976). New product adoption and diffusion. Journal of Consumer Research, 2(4), 290.

Salloum, S. A., Al-Emran, M., Khalaf, R., Habes, M., \& Shaalan, K. (2019). An innovative study of e-payment systems adoption in higher education: Theoretical constructs and empirical analysis. International Journal of Interactive Mobile Technologies (iJIM), 13(06), 68.

Tabitha Wanjiku Murabu \& Zachary Mumbo Mosoti. Factors Promoting and Hindering the Use of Electronic Payment among Kenyans: A Survey of Supermarkets in Thika Town, International Journal of Business and Management Invention ISSN: 2319 - 8028 // Volume 6 Issue 3 // March 2017 // PP 15-23

Tan, G. W., Ooi, K., Chong, S., \& Hew, T. (2014). NFC mobile credit card: The next frontier of mobile payment? Telematics and Informatics, 31(2), 292-307.

Tarhini, A., El-Masri, M., Ali, M., \& Serrano, A. (2016). Extending the UTAUT model to understand the CUSTOMERS' acceptance and use of internet banking in Lebanon. Information Technology \& People, 29(4), 830-849.

Taylor, S., \& Todd, P. A. (1995). Understanding information technology usage: A test of competing models. Information Systems Research, 6(2), 144-176. doi:10.1287/isre.6.2.144

Thompson, R. L., Higgins, C. A., \& Howell, J. M. (1991). Personal computing: Toward a conceptual model of utilization. MIS Quarterly, 15(1), 125. doi:10.2307/249443

Tsiakis, T., \& Sthephanides, G. (2005). The concept of security and trust in electronic payments. Computers \&amp; Security, 24(1), 10-15.

Venkatesh, Morris, Davis, \& Davis. (2003). User acceptance of information technology: Toward a unified view. MIS Quarterly, 27(3), 425.

Venkatesh, V., \& Davis, F. D. (2000). A theoretical extension of the technology Acceptance MODEL: Four Longitudinal field studies. Management Science, 46(2), 186-204. doi:10.1287/mnsc.46.2.186.11926

Yang, S., Lu, Y., Gupta, S., Cao, Y., \& Zhang, R. (2012). Mobile payment services adoption across time: An empirical study of the effects of behavioral beliefs, Social Influences, and personal traits. Computers in Human Behavior, 28(1), 129-142. 